\title{
Decreased Pediatric Viral Burden and Increased Rhinovirus Infection During The COVID-19 Pandemic
}

\section{COVID-19 Pandemisi Sırasında Azalan Pediatrik Viral Yük ve Artan Rinovirüs Enfeksiyonu}

\author{
Metin YIGIT', Aslinur OZKAYA PARLAKAY²
}

1'Department of Pediatrics,Ankara City Hospital, Ankara, Turkey

2Division of Pediatric Infectious Disease, Department of Pediatrics, Yildirim Beyazit University, Ankara City Hospital, Ankara, Turkey

\begin{abstract}
Objective: Primary preventive nonpharmaceutical interventions were introduced to reduce viral transmission and disease spread at the beginning of the COVID-19 pandemic. Therefore, herein, we aimed to determine and assess the impact of the nonpharmaceutical interventions on bronchiolitis and varicella infection rates in the pediatric population during the pandemic compared to the previous four years. We also aimed to evaluate which viruses cause viral respiratory tract infections during the pandemic period.
\end{abstract}

Material and Methods: Diagnosis and laboratory data of the patients who were one month to 18 years of age were retrospectively retrieved from hospital records. The distribution of the number of patients with bronchiolitis and chickenpox diagnoses was shown monthly between January 2016 and December 2020. Viral agents detected by polymerase chain reaction (PCR) in the nasopharyngeal aspirate samples obtained at the first application of the patients during the pandemic period were investigated.

Results: The data of 2.254.877 pediatric patients admitted to our hospital from January 2016 to December 2020 were examined. There were 38.458 bronchiolitis and 954 chickenpox cases reported both as inpatients and outpatients. There was a $85.6 \%$ decrease in the rate of bronchiolitis compared to previous years, and chickenpox peak was not observed in the pandemic period. Rhinovirus was found to be the most common etiologic agent of bronchiolitis during the pandemic period and Respiratory Syncytial Virus (RSV) came second. A significant decrease in the frequency of influenza was also observed.

Conclusion: Our study reveals that the measures which curtail social life and prioritize social distancing prevent the spread of viral infections. It has also shown that there is an increase in the frequency of Rhinovirus infection during the pandemic period.

Key Words: Bronchiolitis, Chickenpox, COVID-19, Rhinovirus

öz

Amaç: COViD-19 pandemisinin bașlangııından itibaren viral bulaşı ve hastalık yayılmasını azaltmak ve engellemek amacıyla dünya genelinde olduğu gibi ülkemizde de medikal olmayan birincil önlemler alındı. Çalışmamızda bu önlemlerin çocuk hastalarda önceki dört ylla göre bronşiolit ve suçiçeği oranlarına etkisini belirlemeyi ve değerlendirmeyi, ayrıca pandemi döneminde viral solunum yolu enfeksiyonlarına hangi etkenlerin sebep olduğunu değerlendirmeyi amaçladık.

Gereç ve Yöntemler: Bir ay ile 18 yaş arasındaki hastaların tanı ve laboratuvar verileri geriye dönük olarak hastane bilgi sisteminden alındı. Bronşiolit ve suçiçeği tanılı hasta sayılarının Ocak 2016' dan Arallk 2020' ye kadar olan aylara göre

(1) 0000-0003-3536-4456: YIGIT M 0000-0001-5691-2461: OZKAYA PARLAKAY A
Conflict of Interest / Çıkar Çatışması: On behalf of all authors, the corresponding author states that there is no conflict of interest.

Ethics Committee Approval / Etik Kurul Onayl: This study was conducted in accordance with the Helsinki Declaration Principles. The study was approved by Ankara City Hospital No. 2 Clinical Research Ethics Committee (E2-20-66/16.12.2020).

Contribution of the Authors / Yazarların katkıII: YIGIT M: Constructing the hypothesis or idea of research and/or article, Planning methodology to reach the Conclusions, Taking responsibility in patient follow-up, collection of relevant biological materials, data management and reporting, execution of the experiments, Taking responsibility in logical interpretation and conclusion of the results, Taking responsibility in necessary literature review for the study, Taking responsibility in the writing of the whole or important parts of the study, Reviewing the article before submission scientifically besides spelling and grammar. OZKAYA PARLAKAY A: Organizing, supervising the course of progress and taking the responsibility of the research/study, Taking responsibility in logical interpretation and conclusion of the results, Taking responsibility in necessary literature review for the study, Reviewing the article before submission scientifically besides spelling and grammar.

How to cite / Atıf yazım şekli : Yigit M and Ozkaya Parlakay A. Decreased Pediatric Viral Burden and Increased Rhinovirus Infection During The Covid-19 Pandemic. Turkish J Pediatr Dis 2022;16:395-401.
Correspondence Address / Yazışma Adresi:

Metin YIGIT

Department of Pediatrics, Ankara City Hospital, Ankara, Turkey

E-posta: metinyigit.md@gmail.com
Received / Geliş tarihi : 21.11 .2021 Accepted / Kabul tarihi : 20.12.2021 Online published Elektronik yayın tarihi

DOI: 10.12956/tchd.1026670 
dağııımı gösterildi. Pandemi döneminde, hastaların ilk başvurusunda alınan nazofaringeal aspirat örneklerinde polimeraz zincir reaksiyonu (polymerase chain reaction, PCR) yöntemiyle saptanan viral etkenler araștırıldı.

Bulgular: Ocak 2016-Aralık 2020 tarihleri arasında hastanemize başvuran 2.254.877 çocuk hastanın verileri incelendi. Toplamda 38.458 bronșiolit ve 954 suçiçeği tanılı hasta vardı. Pandemi döneminde bronșiolit vakalarında önceki yıllara göre \%85.6 oranında azalma görüldü ve önceki yıllarda görülen suçiçeği piklerinin hiçbiri görülmedi. Pandemi döneminde bronşiolit hastalarında en sık etkenin Rhinovirüs olduğu bulundu. Respiratuvar Sinsitiyal Virüs (RSV) ikinci sırada yer aldı. İnfluenza sıklığında da önemli bir azalma gözlendi.

Sonuç: Çalışmamız, sosyal hayatı kısıtlayan ve sosyal mesafeyi ön planda tutan önlemlerin viral enfeksiyonların yayılmasını engellediğini ortaya koymuştur. Ayrıca pandemi döneminde Rhinovirüs enfeksiyonu sıklığında artış olduğunu göstermiştir.

Anahtar Sözcükler: Bronşiolit, Suçiçeği, COViD-19, Rhinovirus

\section{INTRODUCTION}

The novel coronavirus disease (COVID-19), first described in December 2019, has affected a large number of people of all age groups worldwide (1). Current evidence suggests that severe acute respiratory syndrome coronavirus-2 (SARSCoV-2) mainly transmits through respiratory droplets among people who are in close contact with each other. Aerosol transmission can occur in specific settings, particularly in indoor, crowded, and inadequately ventilated spaces $(1,2)$. Since preventive vaccines for COVID-19 or effective drugs to treat the disease have not yet been found, primary preventive nonpharmaceutical interventions, including physical distancing, wearing masks, stay-at-home orders, school closures, strict hand hygiene, and travel restrictions, were introduced to reduce viral transmission and disease spread at the very beginning of the pandemic. These measures are not just specific to reducing the spread of SARSCoV-2 and may impact the epidemiology and transmission of other viruses as well. When COVID-19 infection was first seen in March 2020 in Turkey, we feared that it would put a huge burden on the healthcare system as the clinical manifestations would be confused with other respiratory diseases and viral infections. Surprisingly, according to our observations, the interventions dramatically reduced the burden of pediatric infectious diseases, including influenza, varicella, bronchiolitis, gastroenteritis, common cold, acute otitis media, and urinary tract infections. Therefore, herein, we aimed to determine and assess the impact of the nonpharmaceutical interventions on bronchiolitis and varicella rates of infection in the pediatric population during the pandemic compared to the previous four years.

\section{MATERIALS and METHODS}

We conducted this retrospective cross-sectional study at the Children's Hospital of the Ankara City Hospital, which is a tertiary pediatric hospital in Ankara, the Turkish capital, and among the biggest pediatric hospitals in Europe. About 500.000 patients under the age of 18 years visit our hospital annually. Approximately 40.000 suspected COVID-19 pediatric patients have been followed up and treated as inpatients and outpatients in our hospital since the first case of COVID-19 was documented in Turkey in March 2020.
Patients' diagnosis and laboratory data were retrospectively retrieved from computerized hospital records. The number of the outpatients and inpatients who were admitted to our hospital monthly from January 2016 till January 2021 were analyzed. According to the International Classification of Diseases, Tenth Revision (ICD-10) diagnostic system, the patients diagnosed with bronchiolitis and chickenpox, were determined. The distribution of the number of patients with these diagnoses was shown by month. The bronchiolitis and chickenpox patients were included. All of the bronchiolitis patients were COVID-19 polymerase chain reaction (PCR) negative. Because bronchiolitis and chickenpox are clinical diagnoses, we did not stipulate whether the serology or PCR results were available when including patients with these diagnoses $(3,4)$.

The detection of the respiratory viruses from the patients with bronchiolitis who have undergone PCR testing was performed by the multiplex real-time PCR assay (Rotor-Gene Q, QIAGEN, Germantown, MD) that is capable of identifying viral pathogens including influenza viruses (influenza A, influenza A H1N1, and influenza B), human rhinovirus, human coronaviruses ( $\mathrm{HCoV}$ ) (NL63, 229E, OC43 and HKU1), human parainfluenza viruses (PIV) (PIV-1, PIV-2, PIV-3 and PIV-4), human metapneumoviruses A/B (hMPV), human respiratory synctial viruses $A / B$ (RSV), enterovirus, bocavirus, human adenovirus, and human parechovirus.

A z-test for two proportions (e-picos, 2021) was used to compare the difference between pre-pandemic (2016 and 2019) months' means and pandemic months. The level of statistical significance was established as $p<0.05$. The data were anonymous. Patient-informed consent was not required according to the current dispositions.

The study conformed with the principles of the Declaration of Helsinki and was approved by the local ethics committee and the Institutional Review Board of the Children's Hospital of the Ankara City Hospital (E2-20-66/16.12.2020).

\section{RESULTS}

We examined the data and diagnosis of 2.254 .877 pediatric patients who were admitted to our hospital from January 2016 to December 2020. There were 38.458 bronchiolitis and 954 chickenpox cases reported as both inpatients and outpatients. 


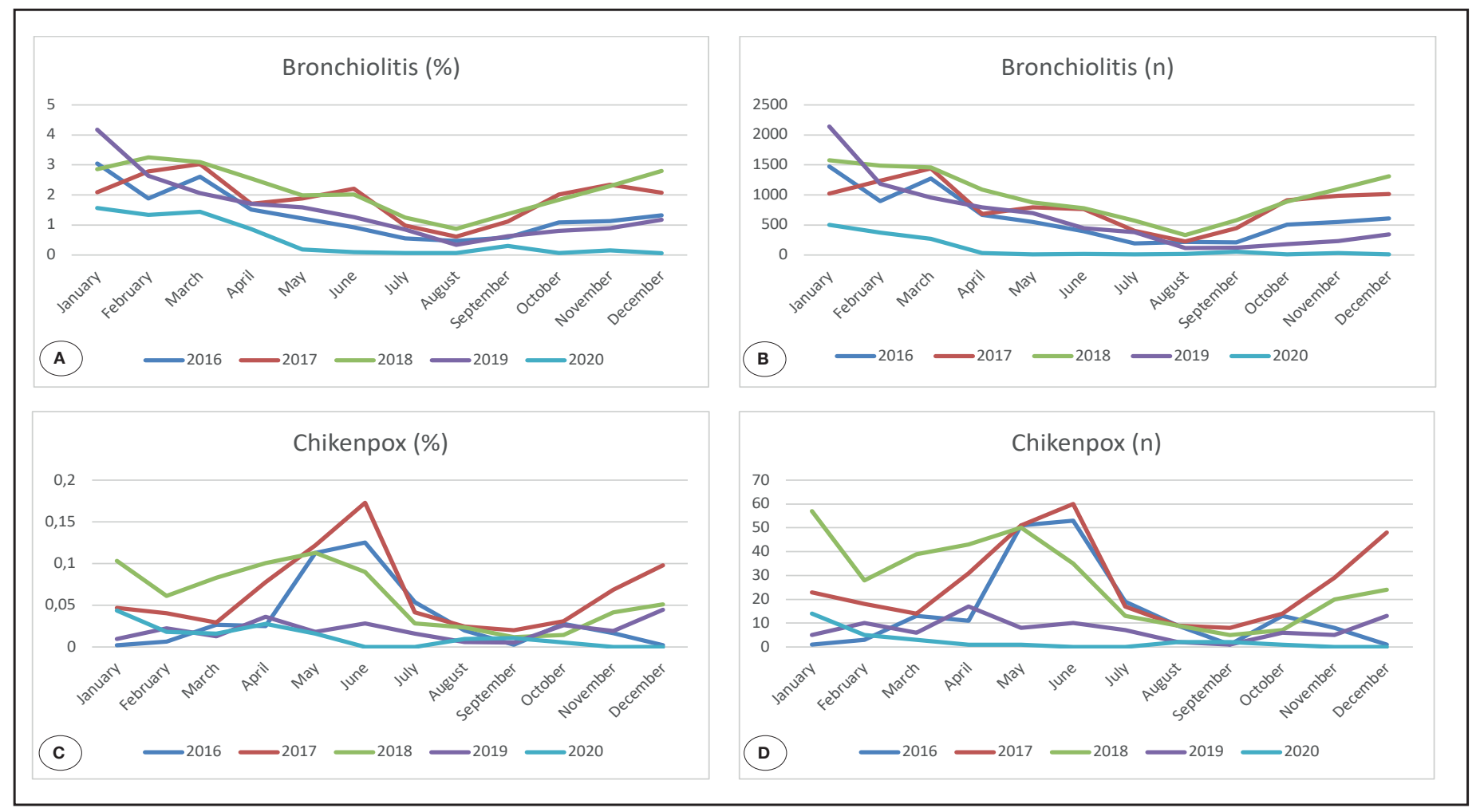

Figure 1: Distribution of the percentage of bronchiolitis $(\mathbf{A})$ and chickenpox $(\mathbf{C})$ cases by years, and distribution of the number of bronchiolitis $(\mathbf{B})$ and chickenpox (D) cases by years.
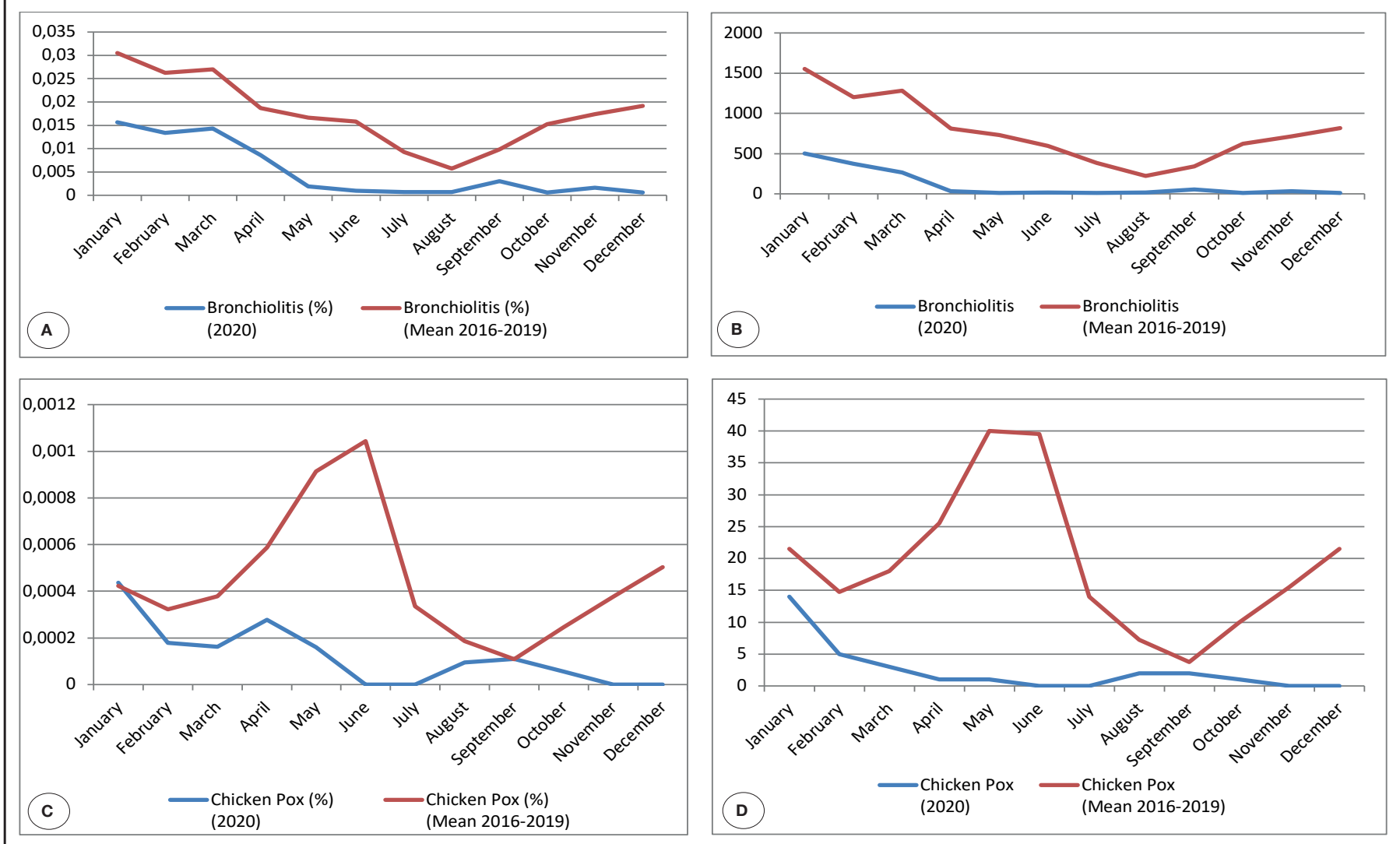

Figure 2: Distribution of the percentage of bronchiolitis (A) and chickenpox (C) cases in 2020 and 2016-2019, and distribution of the number of bronchiolitis (B) and chickenpox (D) cases in 2020 and 2016-2019. 


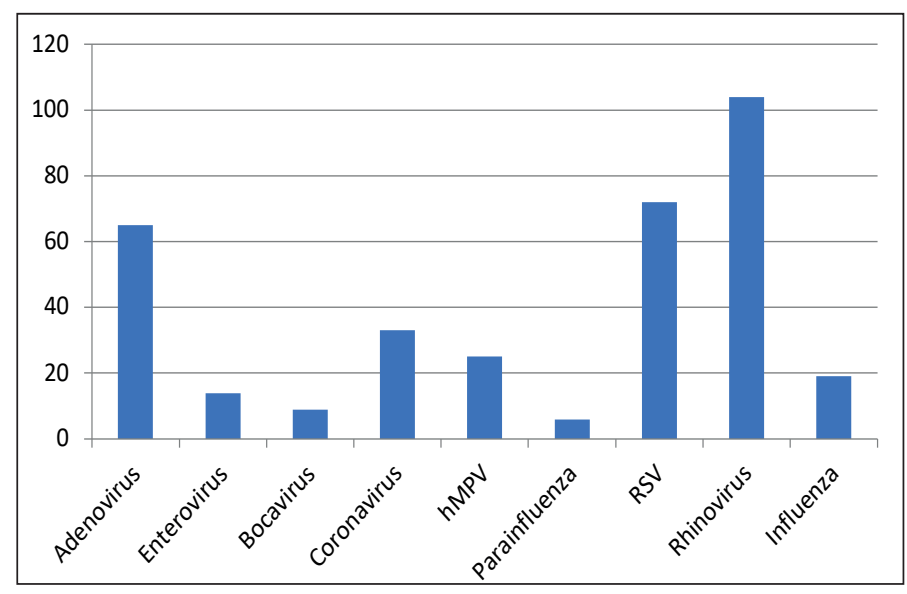

Figure 3: The distribution of the viral pathogens of the bronchiolitis patients in 2020 .

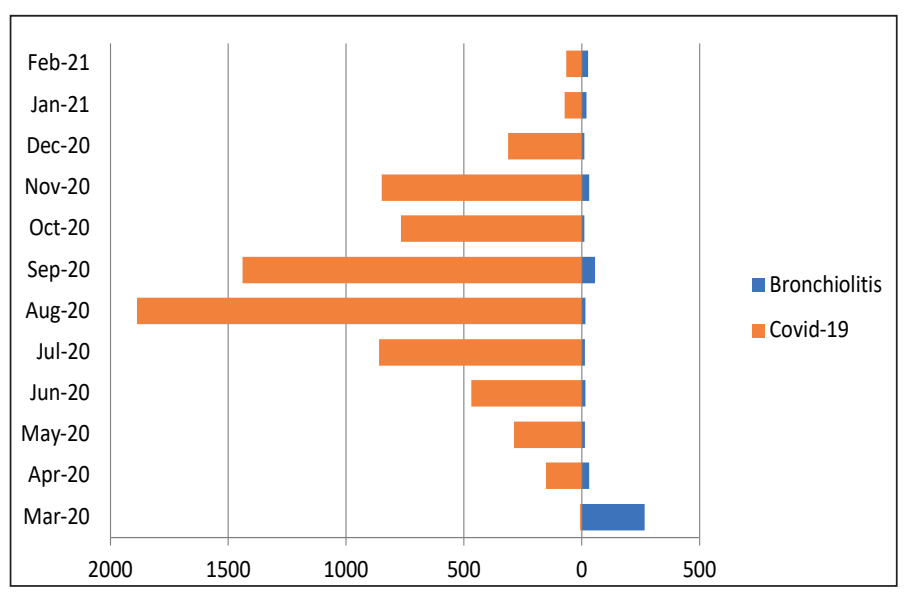

Figure 4: Number of bronchiolitis and COVID-19 cases in 2020.

Table I: Comparation of bronchiolitis admissions in 2020 and 2016-2019.

\begin{tabular}{|c|c|c|c|c|c|c|}
\hline & $\begin{array}{c}\text { Bronchiolitis } \\
(2020) \\
\end{array}$ & $\begin{array}{c}\text { Total Admission } \\
\text { (2020) } \\
\end{array}$ & $\begin{array}{c}\text { Bronchiolitis } \\
\text { (Mean 2016-2019) }\end{array}$ & $\begin{array}{c}\text { Total Admission } \\
\text { (Mean 2016-2019) }\end{array}$ & $\mathbf{Z}^{*}$ & $p$ \\
\hline January & 502 & 32075 & 1553 & 50916 & -13.406 & $<0.001$ \\
\hline February & 374 & 27915 & 1201 & 45671 & -11.731 & $<0.001$ \\
\hline March & 267 & 18605 & 1284 & 47467 & -9.697 & $<0.001$ \\
\hline April & 31 & 3609 & 810 & 43381 & -4.39 & $<0.001$ \\
\hline May & 12 & 6279 & 729 & 43828 & -9.039 & $<0.001$ \\
\hline June & 16 & 15996 & 597 & 37857 & -14.764 & $<0.001$ \\
\hline July & 14 & 19843 & 386 & 41628 & -12.351 & $<0.001$ \\
\hline August & 15 & 21052 & 223 & 38825 & -9.342 & $<0.001$ \\
\hline September & 55 & 18316 & 340 & 34494 & -8.701 & $<0.001$ \\
\hline October & 11 & 18216 & 623 & 40826 & -15.959 & $<0.001$ \\
\hline November & 32 & 19897 & 717 & 41118 & -16.646 & $<0.001$ \\
\hline December & 11 & 18267 & 819 & 42692 & -18.136 & $<0.001$ \\
\hline
\end{tabular}

*Z-test for two proportions (e-picos,2021)

The mean number of bronchiolitis per year in the pre-pandemic and pandemic periods was $9282 \pm 399.4$ and $1340 \pm 170.3$, respectively. The mean number of chickenpox per year in the pre-pandemic and pandemic periods was 232 and 29, respectively. The monthly distribution and the ratio to the overall number of bronchiolitis and chickenpox cases are shown in Figure 1. Over the pre-pandemic period, between 2016 and 2019, the monthly averages of bronchiolitis and chickenpox cases were calculated, and the monthly distribution of each disease was parallel (Figure 2). The mean was compared with the data of the post-pandemic period, and the difference was statistically evaluated (Tables I, II). It was observed that there was a significant decrease in the number and rate of bronchiolitis compared to previous years $(p<0.001)$. A nearly $85 \%$ decrease was observed in bronchiolitis cases in 2020 compared to the previous years. In 2020, the number of bronchiolitis cases did not exceed $30 \%$ of the average of the previous four years. In addition a comparison of monthly bronchiolitis and COVID-19 patient numbers since March 2020, when COVID-19 infection was first seen in Turkey, is shown in Figure 3.

We analyzed the PCR results of bronchiolitis patients who were followed up in our hospital after January 2020. 1191 of 1340 bronchiolitis patients were tested with PCR and 844 were negative. Rhinovirus was found to be the most common etiologic agent in bronchiolitis patients who were negative for COVID-19 during the pandemic period. RSV was in second place. A significant decrease in the frequency of influenza was also observed. The distribution of pathogens detected in 347 positive tests is shown in Figure 4.

The chickenpox vaccine was included in the mandatory vaccination schedule in Turkey in February 2013; therefore, the incidence was low. However, as shown in the graphs, the number of reported chickenpox cases did fluctuate to 
Table II: Comparation of Chicken Pox Admissions in 2020 and 2016-2019.

\begin{tabular}{l|c|c|c|c|c|c}
\hline & $\begin{array}{c}\text { Chicken Pox } \\
(\mathbf{2 0 2 0})\end{array}$ & $\begin{array}{c}\text { Total Admission } \\
\mathbf{( 2 0 2 0 )}\end{array}$ & $\begin{array}{c}\text { Chicken Pox } \\
\text { (Mean 2016-2019) }\end{array}$ & $\begin{array}{c}\text { Total Admission } \\
\text { (Mean 2016-2019) }\end{array}$ & $\mathbf{Z}^{*}$ & p \\
\hline January & 14 & 32075 & 21.5 & 50916 & 0.03 & 0.97 \\
\hline February & 5 & 27915 & 14.75 & 45671 & -1.192 & 0.23 \\
\hline March & 3 & 18605 & 18 & 47467 & -1.414 & 0.15 \\
\hline April & 1 & 3609 & 25.5 & 43381 & -0.776 & 0.43 \\
\hline May & 1 & 6279 & 40 & 43828 & -1.953 & 0.05 \\
\hline June & 0 & 15996 & 39.5 & 37857 & -4.113 & $<0.001$ \\
\hline July & 0 & 19843 & 14 & 41628 & -2.584 & $<0.001$ \\
\hline August & 2 & 21052 & 7.25 & 38825 & -0.813 & 0.42 \\
\hline September & 2 & 18316 & 3.75 & 34494 & -0.069 & 0.94 \\
\hline October & 1 & 18216 & 10 & 40826 & -1.563 & 0.12 \\
\hline November & 0 & 19897 & 15.5 & 41118 & -2.782 & $<0.001$ \\
\hline December & 0 & 18267 & 21.5 & 42692 & -3.069 & $<0.001$ \\
\hline
\end{tabular}

${ }^{*} Z$-test for two proportions (e-picos,2021)

some extent between 2016-2019: the lowest incidence was in September-October and the highest was in June-July and November-December.

\section{DISCUSSION}

Our study is one of the first and most extensive studies on this subject in our country. This study, which was carried out in the largest and most visited children's hospital in Turkey, has shown strikingly and clearly the impact of COVID-19 measures on the spread of other viral diseases, such as bronchiolitis and chickenpox.

In the five-year course of the bronchiolitis cases we examined in our study, the cases of bronchiolitis, which peaked every year in January, reached its highest value in January 2020 but did not reach a peak value as in previous years. A serious decrease was observed in the number of bronchiolitis cases even before the first COVID-19 case in Turkey was reported in March 2020.

The first COVID-19 case in our country was seen on March 11 $1^{\text {th }}$, 2020. With the restriction measures implemented throughout the country as of March $12^{\text {nd }}$, a nearly $85 \%$ decrease was observed in bronchiolitis cases in 2020 compared to the previous years. The restrictions, wearing masks, physical distancing, and school closures during the pandemic were essential precautions that caused this remarkable reduction. The decrease in the transmission in the community as a result of the measures was also reflected in the number of cases. Because the majority of bronchiolitis agents-parainfluenza virus, respiratory syncytial virus, and human rhinoviruses are the most common agents in Turkey-are transmitted by droplets, close contact in community settings, such as schools and daycare centers, is ideal for the spread of viral infections (5-7).
In a multicenter study conducted in France in which the infectious diseases of 2020 and the previous three years were compared, a decrease of more than $70 \%$ was observed, especially in bronchiolitis, the common cold, and acute otitis media (8). In a similar study, it was reported that the most significant decrease in admissions and hospitalizations due to lower respiratory tract infection in the last five years was observed in the 0-2 year age group, among whom acute bronchiolitis is most prevalent (9). In support of this, a study conducted in the United States showed similar results (10).

In the pre-pandemic years, although it was included in the routine vaccination schedule, at least one chickenpox case was observed every month and the highest monthly number of chickenpox cases diagnosed in our center was 60. During the post-March 2020 period, a total of seven cases were detected, and no chickenpox cases were found in several months. In a study conducted in Italy, chickenpox cases decreased by $80 \%$ in 2020 compared to the previous years (11). In a study conducted in the Guangzhou province of China, chickenpox cases in the pediatric and adult populations decreased significantly in 2020 compared to the previous three years (12). In this study, more than half of the cases were found in individuals under the age of 10 . The relationship between the decrease in the number of cases of chickenpox (which is highly contagious) and physical distancing and the closure of indoor public spaces may be stronger than its relationship with the decrease in bronchiolitis cases.

In different studies conducted in different years in our country before the pandemic, when the viral agents of bronchiolitis were examined, the most common cause was RSV, and the second most common cause was Rhinovirus. Influenza and parainfluenza viruses were also among the common causes of bronchiolitis in children in our country (13-15). Klymet et 
al. (16) found in their study which was conducted in Turkey during pandemic period, that the most common detected viral pathogen was rhinovirus on nasopharyngeal swabs for SARSCoV-2 and other common human respiratory tract pathogens. In a study conducted in Japan with 2244 respiratory specimens, it was found that the frequency of influenza and other respiratory viruses was appreciably reduced among all patients during the COVID-19 pandemic except for that of rhinovirus in children younger than 10 years, which was appreciably increased. COVID-19 has not spread among this age group, suggesting an increased risk of rhinovirus infection in children (17). Similar to these studies, in our study, Rhinovirus was found to be the most common agent in bronchiolitis patients who were negative for COVID-19 during the pandemic period. RSV was in second place. A significant decrease in the frequency of influenza was also observed. Rhinovirus is partially resistant to ethanol based disinfectant, and it can survive on environmental surfaces for a prolonged period of time because it is a nonenveloped virüs. These viral properties may be the underlying cause of the relatively increased frequency of rhinovirus (17-19).

Our study attributes the decreases in the rate of bronchiolitis and chickenpox cases to hygiene and social distancing measures taken to control the pandemic. Undoubtfully, these measures must have contributed to the reduction of the transmission of respiratory infectious diseases. In addition, other factors should be taken into account as possible modifiers of epidemiology. Among them, one of the main theories ascribes this epidemiological change to the competition between viruses, in which SARS-CoV-2 would have occupied the ecological niche of other viruses, colonizing the nasopharynx and preventing other viral infections $(20,21)$. These theories should be taken into consideration.

Our study had some limitations. Firstly, it was designed as a retrospective study. Secondly, it was conducted in a single center. In addition, since pre-pandemic respiratory tract PCR results were not available, we could not compare the prepandemic and pandemic PCR results and their changes in our center.

\section{CONCLUSION}

Our study reveals that the measures that curtail social life and prioritize social distancing prevent the spread of infectious diseases other than COVID-19. The effects of the measures implemented across the country on infectious diseases have produced unique results that support the theories of modern medicine. On the other hand, care should be taken in the newnormal period after the pandemic with the spread of vaccination, especially to prevent rebound peaks of viral infections. Patients with diagnoses such as immunodeficiency, malignancy, and chronic lung disease and those in a risk group should continue to take personal precautions for a certain period of time. Comprehensive studies examining this period more closely will be illuminating to the medicine of today and the future.

\section{REFERENCES}

1. Coronavirus disease (COVID-19) n.d. https://uww.who.int/ emergencies/diseases/novel-coronavirus 2019?gclid=CjwKCAiA8ov_ BRAoEiwAOZogwfibNIc27jYPJwX6Ss9frSQcDqU9sp4Y-c5wIJRPmrH13GyLG6s1hoCSVEQAvD_BwE (accessed December 23, 2020).

2. Science Brief: SARS-CoV-2 and Surface (Fomite) Transmission for Indoor Community Environments CDC n.d. https://www.cdc. gov/coronavirus/2019-ncov/more/science-and-research/surfacetransmission.html (accessed June 9, 2021).

3. Friedman JN, Rieder MJ, Walton JM, Chauvin-Kimoff L, Chevalier I, Farrell CA, et al. Bronchiolitis: Recommendations for diagnosis, monitoring and management of children one to 24 months of age. Paediatr Child Heal 2014;19:485.

4. Leung J, Harpaz R, Baughman AL, Heath K, Loparev V, Vázquez $\mathrm{M}$, et al. Evaluation of laboratory methods for diagnosis of varicella. Clin Infect Dis 2010;51:23-32.

5. Aykaç K, Karadağ-öncel E, Bayhan C, Tanır-Başaranoğlu S, Akın MŞ, Özsürekci Y, et al. Prevalence and seasonal distribution of viral etiology of respiratory tract infections in inpatients and outpatients of the pediatric population: 10 year follow-up. Turk J Pediatr 2018;60:642-52.

6. Barker J, Stevens D, Bloomfield SF. Spread and prevention of some common viral infections in community facilities and domestic homes. J Appl Microbiol 2001;91:7-21.

7. Furuse $\mathrm{Y}$, Oshitani $\mathrm{H}$. Mechanisms of replacement of circulating viruses by seasonal and pandemic influenza A viruses. Int J Infect Dis 2016;51:6-14.

8. Angoulvant F, Ouldali N, Yang DD, Filser M, Gajdos V, Rybak A, et al. Coronavirus Disease 2019 Pandemic: Impact Caused by School Closure and National Lockdown on Pediatric Visits and Admissions for Viral and Nonviral Infections - A Time Series Analysis. Clin Infect Dis 2021;72:319-22.

9. Nascimento MS, Baggio DM, Fascina LP, do Prado C. Impact of social isolation due to COVID-19 on the seasonality of pediatric respiratory diseases. PLoS One 2020;15.

10. Wilder JL, Parsons CR, Growdon AS, Toomey SL, Mansbach JM. Pediatric Hospitalizations During the COVID-19 Pandemic. Pediatrics 2020;146.

11. Belingheri M, Paladino ME, Piacenti S, Riva MA. Effects of COVID-19 lockdown on epidemic diseases of childhood. J Med Virol 2021;93:153-4.

12. Wu D, Liu Q, Wu T, Wang D, Lu J. The impact of COVID-19 control measures on the morbidity of varicella, herpes zoster, rubella and measles in Guangzhou, China. Immunity. Inflamm Dis 2020;8:8446.

13. Kanık A, Eliaçık K, Koyun B, Ince OT, Derici YK, Yılmaz NÖ, et al. Viral etiology of acute bronchiolitis in hospitalized infants and the effect on clinical course. Cocuk Enfeksiyon Derg 2016;10:93-8.

14. Pelit S, Bayraktar B, Bulut ME, Karabulut ND, Nuhoğlu A. Investigation of viral agents in lower respiratory tract infections of children by immunofluorescent and immunochromatographic methods. Med Bull Sisli Hosp 2015:118-21. 
15. Azkur D, Ozaydin E, Dibek-Misirlioglu E, Vezir E, Tombuloglu $D$, Kose G, et al. Viral etiology in infants hospitalized for acute bronchiolitis. Viral Etiology of Bronchiolitis 2014;56:592-6.

16. Kıymet E, Böncüoğlu E, Şahinkaya Ş, Cem E, Çelebi MY, Düzgöl M, et al. Distribution of spreading viruses during COVID-19 pandemic: Effect of mitigation strategies. Am J Infect Control 2021;49:1142-5.

17. Takashita E, Kawakami C, Momoki T, Saikusa M, Shimizu K, Ozawa $\mathrm{H}$, et al. Increased risk of rhinovirus infection in children during the coronavirus disease-19 pandemic. Influenza Other Respi Viruses 2021;15:488-94.

18. Savolainen-Kopra C, Korpela T, Simonen-Tikka ML, Amiryousefi A, Ziegler T, Roivainen M, et al. Single treatment with ethanol hand rub is ineffective against human rhinovirus--hand washing with soap and water removes the virus efficiently. J Med Virol 2012;84:543-7.

19. Winther B, McCueK, AsheK, Rubino JR, Hendley JO. Environmental contamination with rhinovirus and transfer to fingers of healthy individuals by daily life activity. J Med Virol 2007;79:1606-10.

20. Vafadar S, Shahdoust M, Kalirad A, Zakeri P, Sadeghi M. Competitive exclusion during co-infection as a strategy to prevent the spread of a virus: A computational perspective. PLoS One 2021;16: e0247200.

21. Hassanin A, Tu VT, Curaudeau M, Csorba and G. The Ecological Niche of SARS-CoV-2-like Viruses in Bats, as Inferred from Phylogeographic Analyses of Rhinolophus Species. Sci Rep 2021;11:14276. 